\title{
Antibacterial potential of symbiont bacteria of brown algae (Turbinaria conoides) obtained from Indonesian waters
}

\author{
NIKEN DHARMAYANTI", ARMA ANTI, RESMI RUMENTA SIREGAR, YULIATI H. SIPAHUTAR, \\ AEF PERMADI, ARPAN NASRI SIREGAR, RANDI BOKHI SALAMPESSY, SUJULIYANI, \\ SITI ZACHRO NURBANI, HENI BUDI PURNAMASARI \\ Program of Fish Processing Technology, Politeknik Ahli Usaha Perikanan. Jl. Pasar Minggu, South Jakarta 12520, Jakarta, Indonesia, \\ Tel.: +62-21-7806874, `email: niken.stp@gmail.com
}

Manuscript received: 7 October 2020. Revision accepted: 26 December 2020

\begin{abstract}
Dharmayanti N, Anti A, Siregar RR, Sipahutar Y, Permadi A, Siregar AN, Salampessy RB, Sujuliyanti, Nurbani SZ, Purnamasari HB. 2021. Title. Biodiversitas 22: 373-377. Brown seaweeds have the potential to produce bioactive compounds. Bacteria associated with seaweeds are involved in the production of metabolites. Microbes may be present as a living symbiotic in association with other algae as epiphytes or endophytes. In this study, bacteria isolated from brown seaweed (Turbinaria conoides) were tested for antibacterial activity. A total of 14 bacteria were isolated, of which 6 were isolated from external tissue, while 8 from internal tissue. Results of an antagonistic test revealed that 7 isolates showed inhibitory activity against Staphylococcus aureus and only 1 isolate showed the inhibition against both $S$. aureus and Escherichia coli. Phenotypic and genotypic analysis showed that the symbiont bacteria was Lactobacillus plantarum.
\end{abstract}

Keywords: Bioassay, brown seaweed, antagonistic, diffusion paper disc, Lactobacillus plantarum

\section{INTRODUCTION}

Seaweed is one of the largest producers of biomass from the ocean and is a potential source of new, diverse, and unique compounds (Bahare et al. 2019). Many substances are obtained from seaweed, such as alginates, carrageenan, and agar, which have been used for decades in traditional medicine, pharmacology, and food (Andrea et al. 2019). Other compounds have bacteriostatic or antibacterial, antiviral, anti-tumor, anti-inflammatory, and antifouling activity. Therefore, seaweed can provide promising bioactive that can be used in the treatment of human diseases or new antimicrobial agents to replace synthetic antibacterial agents used in agriculture and the food industry. Seaweed applications are particularly used in the design of new antimicrobial drugs. Research for the identification of promising algal species, standardization of analytical methods, isolation of compounds through integrated fractionation of bioassays, detailed chemical characterization and evaluation of their safety, evaluation of synergistic effects between components, and efforts to improve yields and lowering extraction costs is needed (Marie et al. 2016).

In later decades, strides microbiological procedures have altogether made a difference in build-up phylogenetic affiliations of seaweed-related epi-bacterial communities and endophytes. Be that as it may, there is inadequately prove that utilitarian connections for seaweed-bacterial intuitive can be built up and well caught on. Epiphytic bacterial communities are rapid colonizers of the ocean growth surface, some of the time versatile and able to quickly metabolize algal exudates (Singh and Reddy 2014).
It has traditionally been used for children's fever, as a fertilizer, repellent, including antioxidant, anti-inflammatory, antimicrobial, and anti-cancer (Gupta and Abu-Ghannam 2011). Seaweeds can secrete secondary metabolites with antibacterial properties (Shannon and Abu-Ghannam 2016). The symbiotic mutualism occurs as algae provide essential sites and nutrients, while the bacteria encourage growth and protect the algal surface against symbiont bacteria isolates as algae have abundant antimicrobial activity. The existence of the bacteria is suspected as a result of infections acquired from the community (Arumugama et al. 2017). Turbinaria conoides is a tropical marine alga widely distributed in coastal waters in Asia.

This study evaluates the properties of the brown alga Turbinaria conoides in producing bioactive compounds including the inhibition of human pathogens.

\section{MATERIALS AND METHODS}

\section{Sampling}

Samples of Turbinaria conoides (about $1 \mathrm{~kg}$ wet weight) were taken from Lima island, Serang City, Banten, Indonesia (S: -6.001051; E: 106.153804). Samples were maintained in fresh seawater for laboratory analysis within 24 hours of collection.

\section{Isolation of symbiont bacteria producing antibacterial compounds}

Bacteria were isolated in a solid medium and the size of the colony was different for each species and was characteristic of a particular species (Sanders 2012). 
Epibionts were extracted from 15 grams of algae by rinse in with $30 \mathrm{~mL}$ of sterile seawater. The rinse water was incubated in $30 \mathrm{~mL}$ of nutrient broth medium and shaken at room temperature for 24 hours. The bioactive compound was extracted by crushing $15 \mathrm{~g}$ of alga with a mortar and pestle with the addition of $15 \mathrm{~mL}$ of sterile seawater. The suspension was insert into a $30 \mathrm{~mL}$ nutrient broth medium and shaken at room temperature for 24 hours.

After the extraction process, $1 \mathrm{~mL}$ of refresh samples were diluted in a $9 \mathrm{~mL}$ of sterile nutrient broth to make $10^{-1}$ dilution. This process was continued to achieve $10^{-5}$ dilutionEach dilution was grown on a plate count agar medium by incubating them at $37^{\circ} \mathrm{C}$ for $2 \times 24$ hours. Colonies of bacteria that produce antimicrobial compounds were characterized by a clear zone. Furthermore, the colonies with stable inhibition zones were collected by isolating them on a slant agar medium.

\section{Selection of symbiont bacteria isolates antagonistically against pathogenic bacteria}

For this, a qualitative test was carried out directly by scratching the isolates on the surface of the media that has been dispersed with two test bacteria, i.e. Escherichia coli and Staphylococcus aureus (Monte et al. 2014)). The media was then incubated for 48 hours at $37^{\circ} \mathrm{C}$. Each scratching round of isolates was then marked by a unique code. Inhibition zones were showing clear zones around the colony of symbiont bacteria isolates for both $E$. coli and $S$. aureus. Strains that showed maximum antagonistic effect against tested pathogens were identified. Strains showing maximum antagonistic effects were isolated and selected for antibacterial testing by the paper disc diffusion method. Further, the strains were identified at the phenotypic and genotypic levels.

\section{Antibacterial potential testing of symbiont bacterial isolate by paper disc diffusion}

Antibacterial testing of symbiont bacteria for inhibitory growth of $E$. coli and $S$. aureus was performed by the paper disc diffusion method (Grela et al. 2018). The supernatant was obtained by separating the filtrate and the supernatant was centrifuged for 1 hour $\left(25^{\circ} \mathrm{C}\right.$ and $\left.3000 \mathrm{rpm}\right)$. Paper discs containing $40 \mu \mathrm{L}$ supernatant was considered as the treatment while $40 \mu \mathrm{L}$ nutrient broth was used in negative control and chloramphenicol $(0.01 \mathrm{mg} / \mathrm{mL})$ was used as a positive control. After that, the discs were placed on the surface of the Mueller Hinton Agar medium containing 1 $\mathrm{mL}$ test bacteria and incubated for 48 hours at $37^{\circ} \mathrm{C}$. The supernatant diffuses from the disc into the agar. The presence of a clear zone around the supernatant and antibiotic discs was measured by the meter rule in $\mathrm{mm}$. The zone sizes were compared to assess bioactivity as sensitive, resistant, or intermediate, and the presence of a clear zone was measured by the meter rule in $\mathrm{mm}$.

\section{Identification of symbiont bacteria phenotype and genotype}

General bacterial identification based on colony characteristic observations on liquid medium and solid medium followed by cell morphology (gram staining, spore staining, and Ziehl-Neelsen staining), and biochemical test (motility, gelatin hydrolysis, citrate, urease, carbohydrates, and catalase) as described by Phumudzo et al. (2013). The initial selection of isolates from mixed cultures was carried out after enrichment and planting of $T$. conoides samples on the agar medium. The plates were incubated at $37^{\circ} \mathrm{C}$ temperature for 24 to 48 hours. The data obtained from the bacterial isolate characterization were used to estimate the type of symbiotic bacteria isolated from $T$. conoides. The DNA of the symbiont bacteria isolated was amplified using primers $9 \mathrm{~F}$ and $1541 \mathrm{R}$. The DNA bands used were relevant to the resulting PCR product of about 1400 base pairs. The PCR reaction used a PCR machine (Eppendorf German) with a first pre-denaturation at $94^{\circ} \mathrm{C}$ for 90 seconds, followed by 30 cycles consisting of denaturation at $95^{\circ} \mathrm{C}$ for 30 seconds, primary attachment at $50^{\circ} \mathrm{C}$ for 30 seconds, and extension at $72^{\circ} \mathrm{C}$ for 90 seconds, followed by the elongation phase at $72^{\circ} \mathrm{C}$ for $5 \mathrm{~min}$ and cooling at $4^{\circ} \mathrm{C}$ for $20 \mathrm{~min}$. Molecular identification was done through partial genetic analysis of $16 \mathrm{~S}$ rDNA. DNA extraction was performed using the GES method (Pitcher et al. 1989 modified). PCR Amplification on 16S rDNA using Primer 9 F: 5 - AAG GAG GTG ATC CAG CC-3` and Primer 1541 R: 5 - GAG TTT GAT CCT GGC TCA G - 3' (White et al. 1990, O`Donnell 1993). The analysis of nitrogen base sequence readings was performed with an automated DNA sequencer (ABI PRISM 3130 Genetic Analyzer) (Applied Biosystems). The next sequenced raw data were trimmed and assembled using the BioEdit program (http://www.mbio.ncsu.edu/BioEdit/bioedit.html). Sequencing data were assembled in BLAST with genomic data registered in DDBJ/DNA Data Bank of Japan (http://blast.ddbj.nig.ac.jp/).

\section{RESULTS AND DISCUSSION}

\section{The result of symbiont bacteria isolation}

A total of 14 colonies were isolated, of which 6 were from epibionts while the other 8 were from algal tissue. The macroscopic results of colonies on mixed cultures can be seen in Table 1, and on slant agar can be seen in Table 2.

\section{The selection results symbiont bacteria producing antibacterial compounds}

Based on the results of the direct challenge test, only 5 bacterial isolates i.e. TUL2-B1-2, TUL2-B2-2, TUD2-D22, TUD2-D3-2, and TUD3-F-2 showed inhibitory activity against S.aureus whereas only 2 viz. TUD4-C1-2 and TUD4-C2-2 bacterial isolates showed inhibition zones against both pathogenic bacteria. The inhibition activity was found to be lower in E. coli than in S. aureus (Figures 1 and 2).

Isolates with code TUD4-C2-2 had the best inhibition zone. Bacterial isolates derived from algal tissue showed better inhibition than isolates derived from epibionts. The inhibitory zone and diameter measurement results against $S$. aureus and E. coli can be seen in Figure 3 and Table 3 .

Positive controls showed $16.8 \mathrm{~mm}$ inhibition zone against $S$. aureus and $138 \mathrm{~mm}$ inhibition zone against $E$. coli. Chloramphenicol with a concentration of $0.03 \mathrm{mg}$ on a 
paper disc is highly active if its inhibition zone is more than $18 \mathrm{~mm}$ (Mounyr et al. 2016), while the dose of chloramphenicol (positive control) used was less than 0.01 $\mathrm{mg}$, so it can be said that bacteria test was found to be sensitive to the positive control. Negative control (NB without symbiotic bacterial inoculation) indicates the absence of activity or inhibition zone, so it can be ascertained that supernatant does not affect the activity formed.

Tabel 1. Macroscopic forms of bacterial colonies.

\begin{tabular}{|c|c|c|c|c|}
\hline \multirow{2}{*}{$\begin{array}{l}\text { Colony } \\
\text { code }\end{array}$} & \multicolumn{4}{|c|}{ Morphology of colonies } \\
\hline & Shape & Color & Edges & Elevation \\
\hline TUL $^{2}-\mathrm{A} 1-2$ & Round & White & Flat & Convex shiny \\
\hline $\mathrm{TUL}^{2}-\mathrm{A} 2-2$ & Round & White & Flat & Convex shiny \\
\hline $\mathrm{TUL}^{2}-\mathrm{A} 3-2$ & Round & White & Flat & Convex shiny \\
\hline $\mathrm{TUL}^{2}-\mathrm{A} 4-2$ & Round & White & Flat & Convex shiny \\
\hline TUL $^{2}-\mathrm{B} 1-2$ & Round & White & Crooked & Convex shiny \\
\hline $\mathrm{TUL}^{2}-\mathrm{B} 2-2$ & Round & White & Crooked & Convex shiny \\
\hline $\mathrm{TUD}^{4}-\mathrm{C} 1-2$ & Round & White & Flat & Convex shiny \\
\hline $\mathrm{TUD}^{4}-\mathrm{C} 2-2$ & Round & White & Flat & Convex shiny \\
\hline TUD $^{2}-\mathrm{D} 1-2$ & Round & White & Crooked & Convex shiny \\
\hline $\mathrm{TUD}^{2}$-D2-2 & Round & White & Crooked & Convex shiny \\
\hline TUD $^{2}-\mathrm{D} 3-2$ & Round & White & Crooked & Convex shiny \\
\hline TUD $^{2}$-D4-2 & Round & White & Crooked & Convex shiny \\
\hline TUD $^{5}-\mathrm{E}-2$ & Round & White & Flat & Convex shiny \\
\hline $\mathrm{TUD}^{3}-\mathrm{F}-2$ & Round & White & Flat & Convex shiny \\
\hline
\end{tabular}

Note: *The code of isolates TUL/TUD states the isolates originating from the outer/inner algae. $* *$ The code of isolates $\left({ }^{2}\right)$, $\left({ }^{4}\right),\left({ }^{5}\right),\left({ }^{3}\right)$ states isolates obtained from the dilution. $* * *$ The code of isolates $\mathrm{A} 1$ and so on, $\mathrm{B} 1$ and $\mathrm{C} 1$ so on, $\mathrm{D} 1$ so on, E, F, the letter codes denote the observed gradient sequence and the number code representing isolates in the order of the first, second, and so on according the best inhibition zone of each colony observed on the plate. $* * * *$ The code of number 2 identifies the isolate obtained from the second repeat

Table 2. Macroscopic form of the isolates on slant agar

\begin{tabular}{|c|c|c|}
\hline \multirow{2}{*}{ Code of isolates } & \multicolumn{2}{|c|}{ Solid medium } \\
\hline & Shape & Color \\
\hline TUL $^{2}-\mathrm{A} 1-2$ & Spread & Milky white \\
\hline $\mathrm{TUL}^{2}-\mathrm{A} 2-2$ & Spread & Milky white \\
\hline $\mathrm{TUL}^{2}-\mathrm{A} 3-2$ & Spread & Milky white \\
\hline $\mathrm{TUL}^{2}-\mathrm{A} 4-2$ & Spread & Milky white \\
\hline $\mathrm{TUL}^{2}-\mathrm{B} 1-2$ & Rhizoidal & Cloudy white \\
\hline TUL $^{2}-B 2-2$ & Rhizoidal & Cloudy white \\
\hline TUD $^{4}-\mathrm{C} 1-2$ & Spread & Milky white \\
\hline TUD $^{4}-\mathrm{C} 2-2$ & Spread & Milky white \\
\hline TUD $^{2}-\mathrm{D} 1-2$ & Rhizoidal & Cloudy white \\
\hline TUD $^{2}-\mathrm{D} 2-2$ & Rhizoidal & Cloudy white \\
\hline TUD $^{2}$-D3-2 & Rhizoidal & Cloudy white \\
\hline TUD $^{2}-\mathrm{D} 4-2$ & Rhizoidal & Cloudy white \\
\hline TUD 5 -E-2 & Spread & Milky white \\
\hline TUD $^{3}-\mathrm{F}-2$ & Spread & Milky white \\
\hline
\end{tabular}

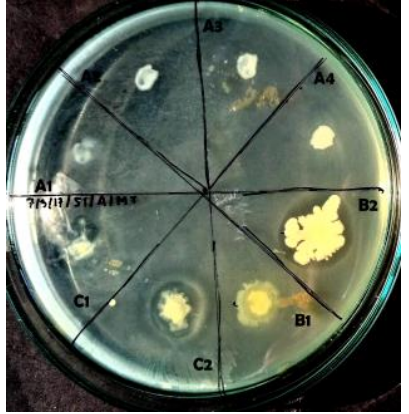

A

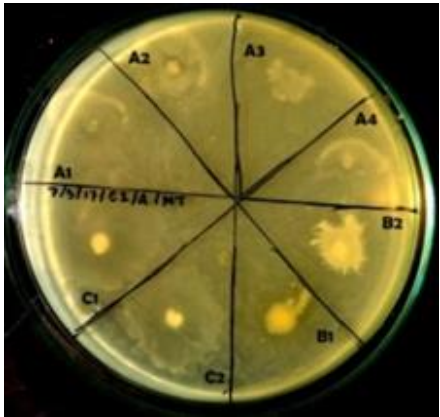

B
Figure 1. Symbiont bacterial isolates (A1, A2, A3, A4, B1, B2, $\mathrm{C} 1, \mathrm{C} 2$ ) on a direct challenge test to Staphylococcus aureus (A) and Escherichia coli (B)

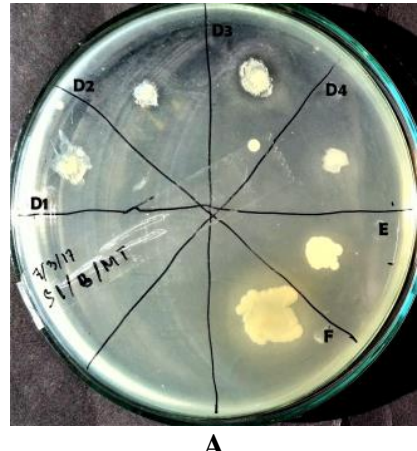

A

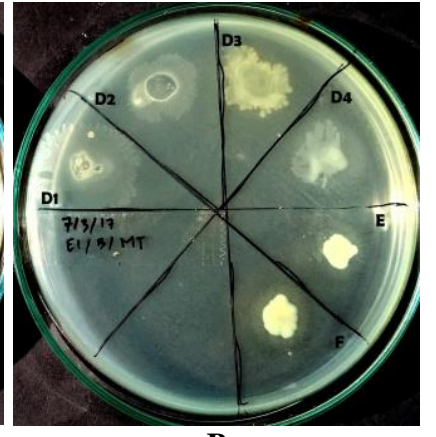

B
Figure 2. Symbiont bacterial isolates (D1, D2, D3, D4, E, F) on a direct challenge test to Staphylococcus aureus (A) and Escherichia coli (B)

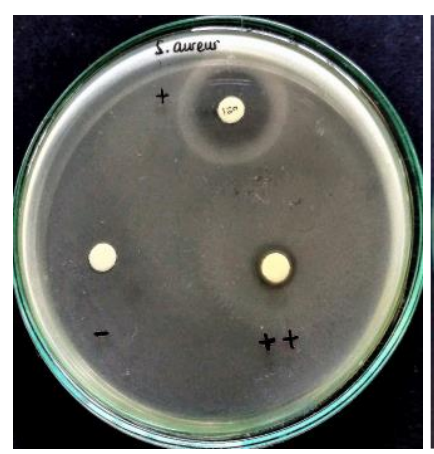

A

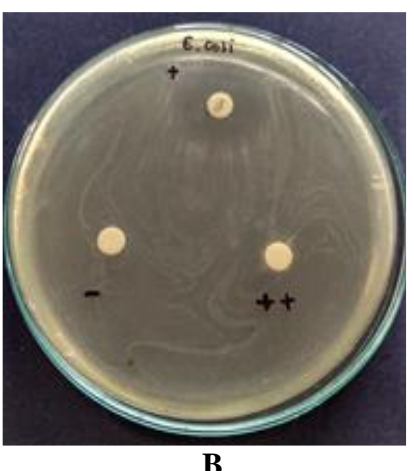

B
Figure 3. Results of antibiotic susceptibility test against: A. Staphylococcus aureus and B. Escherichia coli

Table 3. Results of inhibitory zone diameter

\begin{tabular}{ccccccc}
\hline & \multicolumn{4}{c}{ The diameter of zone inhibition (mm) } \\
\cline { 2 - 7 } Repetition & \multicolumn{3}{c}{ Gram-positive } & \multicolumn{3}{c}{ Gram-negative } \\
\cline { 2 - 7 } & $\begin{array}{c}\text { Symbiont bacterial } \\
(++)\end{array}$ & $\begin{array}{c}\text { Control } \\
(+)\end{array}$ & $\begin{array}{c}\text { Control } \\
(-)\end{array}$ & $\begin{array}{c}\text { Symbiont bacterial } \\
(++)\end{array}$ & $\begin{array}{c}\text { Control } \\
(+)\end{array}$ & $\begin{array}{c}\text { Control } \\
(-)\end{array}$ \\
\hline 1 & 5.5 & 16 & 0 & 0 & 13.5 & 0 \\
2 & 7.8 & 17.5 & 0 & 0 & 0 & 14 \\
Average & 6.7 & 16.8 & 0 & 0 & 13.8 & 0 \\
\hline
\end{tabular}


The antibacterial properties of the supernatant produced by the symbiotic bacteria act as inhibitors against Grampositive bacteria and were merely bacteriostatic for Gramnegative bacteria. As gram-positive symbiotic bacteria widely know contain bacteriocins (Mezaini et al. 2009; Li et al. 2015) bacteriocins from Gram-positive bacteria are generally not effective against Gram-negative bacteria (Smaoui et al. 2010). Paper disc with supernatant applied to a Gram-positive bacterial plate indicate a stable clear zone even after a 48-hour incubation period. While against the Gram-negative bacteria, the presence of inhibitory activity appeared around the disc paper, but it was gradually turbulent before the incubation period reaches 24 hours. The antibacterial compounds produced by symbiont bacterial isolates showed different inhibitory activity against both tested bacteria S.aureus and E.coli. According to Soria-Mercado et al. (2011), the inner symbiotic bacteria generally have abundant populations and are specific because they directly interact with the bioactive compounds produced from within the algae. While the symbiotic bacteria were less populated, as it required higher defense power to overcome the pathogens and predators that are around the algae.

Antimicrobial agents may be bacteriostatic at low concentrations but are bactericidal at high concentrations (Baquero and Levin 2020). Other factors that affect the inhibition potential are the concentration or intensity of antimicrobial agents, the number of microorganisms, the temperature, the species of microorganisms, the presence of organic matter, and the degree of acidity $(\mathrm{pH})$ (Manisha and Shyamapada 2011).

The area of the symptomatic supernatant inhibition zone of S.aureus was $6.7 \mathrm{~mm}$. According to Mounyr et al. (2016), less than $10 \mathrm{~mm}$ inhibition zone showed weak activity and if the inhibition zone is greater than $15 \mathrm{~mm}$ it indicates strong activity. Testing of antibacterial activity of the symbiont bacteria supernatant obtained was still far from the results of the antibiotic activity of the chloramphenicol control. This is because of the supernatant containing secondary metabolites. However, the test results provide clear evidence of antibacterial activity. Generally, the chemical structure of metabolites from marine products differs from the terrestrial origin. Marine bacteria are significant reservoirs of bioactive molecules that have never been found in terrestrial organisms (Barzkar et al. 2019). Seawater contains an active inhibitor agent for Gram-positive bacteria (Kapoor et al. 2017).

\section{Identification of phenotype and genotype of symbiont bacteria}

The known characteristics of symbiont bacteria through phenotypic observation and biochemical tests include rodshaped, non-acidic, non-spore-forming, non-motile, grow aerobically, negative catalase, and positive carbohydrate test In general, the selected isolate showed special characteristics possessed by lactic acid bacteria (Lactobacillus spp.), such as circular, smooth white, Grampositive colonies with brief stem cells, without shaping endospores (Davoodabadi et al. 2015).

The molecular identification was done through partial genetic analysis of $16 \mathrm{~S}$ rDNA. PCR amplification results from the $16 \mathrm{~S}$ region of bacterial ribosome DNA Nitrogen base sequences sorted from symbiont bacterial isolates can be seen in Figure 4. The sequencing information was under the influence of genomic information enlisted within the DDBJ/Japanese DNA Information Bank with $100 \%$ strains grouping comes about. The characters of the antibacterial strains were indistinguishable from those of Lactobacillus plantarum. The highest $100 \%$ personality, greatest score 2660, add up to score 2660, 100\% inquiry scope, E esteem 0, was recorded for the taxon of adjacent microbes. The classification of the bacterial isolate is Bacteria; Firmicutes; Bacilli; Lactobacillales; Lactobacillaceae; Lactobacillus; Lactobacillus plantarum.

Sequens of $16 \mathrm{~S}$ rDNA

GCTCAGGACGAACGCTGGCGGCGTGCCTAATACATGCAAGTCGAACGAACTCTGGTATTGATTGGTGCTTGCATCATGATTTACATTTGAG TGAGTGGCGAACTGGTGAGTAACACGTGGGAAACCTGCCCAGAAGCGGGGGATAACACCTGGAAACAGATGCTAATACCGCATAACAACTT GGACCGCATGGTCCGAGCTTGAAAGATGGCTTCGGCTATCACTTTTGGATGGTCCCGCGGCGTATTAGCTAGATGGTGGGGTAACGGCTCA CCATGGCAATGATACGTAGCCGACCTGAGAGGGTAATCGGCCACATTGGGACTGAGACACGGCCCAAACTCCTACGGGAGGCAGCAGTAGG GAATCTTCCACAATGGACGAAAGTCTGATGGAGCAACGCCGCGTGAGTGAAGAAGGGTTTCGGCTCGTAAAACTCTGTTGTTAAAGAAGAA CATATCTGAGAGTAACTGTTCAGGTATTGACGGTATTTAACCAGAAAGCCACGGCTAACTACGTGCCAGCAGCCGCGGTAATACGTAGGTG GCAAGCGTTGTCCGGATTTATTGGGCGTAAAGCGAGCGCAGGCGGTTTTTTAAGTCTGATGTGAAAGCCTTCGGCTCAACCGAAGAAGTGC ATCGGAAACTGGGAAACTTGAGTGCAGAAGAGGACAGTGGAACTCCATGTGTAGCGGTGAAATGCGTAGATATATGGAAGAACACCAGTGG CGAAGGCGGCTGTCTGGTCTGTAACTGACGCTGAGGCTCGAAAGTATGGGTAGCAAACAGGATTAGATACCCTGGTAGTCCATACCGTAAA CGATGAATGCTAAGTGTTGGAGGGTTTCCGCCCTTCAGTGCTGCAGCTAACGCATTAAGCATTCCGCCTGGGGAGTACGGCCGCAAGGCTG AAACTCAAAGGAATTGACGGGGGCCCGCACAAGCGGTGGAGCATGTGGTTTAATTCGAAGCTACGCGAAGAACCTTACCAGGTCTTGACAT ACTATGCAAATCTAAGAGATTAGACGTTCCCTTCGGGGACATGGATACAGGTGGTGCATGGTTGTCGTCAGCTCGTGTCGTGAGATGTTGG GTTAAGTCCCGCAACGAGCGCAACCCTTATTATCAGTTGCCAGCATTAAGTTGGGCACTCTGGTGAGACTGCCGGTGACAAACCGGAGGAA GGTGGGGATGACGTCAAATCATCATGCCCCTTATGACCTGGGCTACACACGTGCTACAATGGATGGTACAACGAGTTGCGAACTCGCGAGA GTAAGCTAATCTCTTAAAGCCATTCTCAGTTCGGATTGTAGGCTGCAACTCGCCTACATGAAGTCGGAATCGCTAGTAATCGCGGATCAGC ATGCCGCGGTGAATACGTTCCCGGGCCTTGTACACACCGCCCGTCACACCATGAGAGTTTGTAACACCCAAAGTC

Figure 4. The arrangement of nitrogen bases sequenced from symbiont bacteria, A: adenine, T: thiamine, G: guanine, C: cytosine 
Data for base sequence encoding gene of 16S rDNA shows that symbiont bacteria have accurate scores for species levels with a similarity of $100 \%$ of the sequences present in GenBank. The species homology of the tested isolate was $L$. plantarum. L. plantarum strains separated from dairy items appeared solid antimicrobial action against the pointers strains of $S$. aureus, Salmonella spp, and E. coli (Hu et al. 2019). The isolation of L. plantarum from Tibetan yaks was able to restrain the development of $E$. coli and S. aureus (Wang et al. 2018). Some Lactobacillus strains showed antibacterial movement against Enterobacteriaceae that were safe for carbapenems (CRE). This effect may have potential applications through the utilize of the Lactobacillus strain as a starter culture in aged nourishments or as a nourishment additive to control or avoid CRE contamination (Chen et al. 2019).

In conclusion, $T$. conoides was commonly found in the gulf of Banten, Serang district, province of Banten. This research revealed that symbiont bacteria $L$. plantarum was endophytic and potentially useful as an antibacterial agent against common pathogens.

\section{ACKNOWLEDGEMENTS}

The research behind this paper would not have been possible without the exceptional support by Jakarta Technical Fisheries University, Indonesia under the Applied Research Program of Fish Processing Technology Study Program. The authors thank the Jakarta Technical Fisheries University for providing scientific publication funding.

\section{REFERENCES}

Andrea GZ, Miguel A. Prieto L, Cecilia J-Lopez, Juan C. Mejuto, Jesus SGandara. 2019. The potential of seaweeds as a source of functional ingredients of prebiotic and antioxidant value. Antioxid (Basel) 8 (9): 406.

Arumugama P, Kavipriya R, Murugan M, Ramar M, Kamalakannan S, Murugan K 2017. Antibacterial, antioxidant, and anticancer properties of Turbinaria conoides (J. Agardh). Clin Phytosci 3: 5. DOI: 10.1186/s40816-017-0042-y.

Bahare S, Javad SR, Ana ML. Seca, Diana CGA. Pinto, Izabela M, Antonio T, Abhay PM, Manisha N, Wissam Z, Natália M. 2019. Current trends on seaweeds: looking at chemical composition, phytopharmacology, and cosmetic applications. Molecules 24 (22): 4182.

Baquero F, Levin BR. 2020. Proximate and ultimate causes of the bactericidal action of antibiotics. Nat Rev Microbiol. DOI: 10.1038/s41579-020-00443-1.

Barzkar N, Jahromi ST, Poorsaheli HB, Vianello F. 2019. Metabolites from marine microorganisms, micro, and macroalgae: immense scope for pharmacology. Mar Drugs 17 (8): 464. DOI: $10.3390 / \mathrm{md} 17080464$.

Chen CC, Lai CC, Huang HL, Huang WY, Toh HS, Weng TC, Chuang YC, Lu YC, Tang HJ. 2019. Antimicrobial activity of Lactobacillus species against carbapenem-resistant Enterobacteriaceae. Front Microbiol 10: 789. DOI: 10.3389/fmicb.2019.00789.

Davoodabadi A, Soltan Dallal MM, Rahimi Foroushani A, Douraghi M, Sharifi Yazdi MK, Amin Harati F. 2015. Antibacterial activity of Lactobacillus spp. isolated from the feces of healthy infants against enteropathogenic bacteria. Anaerobe 34: 53-58.

Grela E, Kozłowska J, Grabowiecka. 2018. A. Current methodology of MTT assay in bacteria-a review. Acta Histochem 120 (4): 303-311

Gupta S, Abu-Ghannam N. 2011/Bioactive potential and possible health effects of edible brown seaweeds. Trends Food Sci Technol 22: 315326.

Hu CH, Ren LQ, Zhou Y, Ye BC. 2019. Characterization of antimicrobial activity of three Lactobacillus plantarum strains isolated from Chinese traditional dairy food. Food Sci Nutr 7 (6): 1997-2005. DOI: 10.1002/fsn3.1025.

Kapoor G, Saigal S, Elongavan A. 2017. Action and resistance mechanisms of antibiotics: A guide for clinicians. J Anaesthesiol Clin Pharmacol 33 (3): 300-305.

Li D, Ni K, Pang H, Wang Y, Cai Y, Jin Q. 2015. Identification and antimicrobial activity detection of lactic acid bacteria isolated from corn stover silage. Asian-Australas J Anim Sci 28 (5): 620-631.

Manisha DM, Shyamapada M. 2011. Honey: its medicinal property and antibacterial activity. Asian Pac J Trop Biomed1 (2): 154-160.

Mari JP, Elena F, Herminia D. 2016. Antimicrobial action of compounds from marine seaweed. Mar Drugs 14 (3): 52. DOI: 10.3390/md14030052.

Mezaini A, Chihib NE, Bouras AD, Arroume NN, Hornez JP. 2009. Antibacterial activity of some lactic acid bacteria isolated from an algerian dairy product. J Environ Public Health 2009: 678495. DOI: 10.1155/2009/678495..

Monte J, Abreu AC, Borges A, Simões LC, Simões M. 2014. Antimicrobial activity of selected phytochemicals against Escherichia coli and Staphylococcus aureus and their biofilms. Pathogens (Basel, Switzerland) 3 (2): 473-498

Mounyr B, Moulay S, Saad KI. 2016. Methods for in vitro evaluating antimicrobial activity: A review J Pharm Anal 6 (2): 71-79.

O’Donnell. 1993. Fusarium and its near relatives. In: Reynolds DR, Taylor JW (eds.). The Fungal Holomarph Mititic, Meiotic and Pleomorpic Speciation in Fungal Systematic. CAB International, Wallingford, UK.

Phumudzo T, Ronald N, Khayalethu N, Fhatuwani M. 2013. Bacterial species identification getting easier. Afr J Biotechnol 12 (41): 59755982

Sanders ER. 2012. Aseptic Laboratory Techniques: Plating Methods. J Vis Exp 63: e3064. DOI: 10.3791/3064.

Shannon E, Abu-Ghannam N. 2016. Antibacterial derivatives of marine algae: An overview of pharmacological mechanisms and applications. Mar Drugs 14 (4): 81. DOI: 10.3390/md14040081.

Singh RP, Reddy CRK. 2014. Seaweed-microbial interactions: key functions of seaweed-associated bacteria. FEMS Microbiol Ecol 88 (2): 213-230.

Smaoui S, Elleuch L, Bejar W, Karray-Rebai I, Ayadi I, Jaouadi B, Mathieu F, Chouayekh H, Bejar S, Mellouli L. 2010. Inhibition of fungi and gram-negative bacteria by bacteriocin BacTN635 produced by Lactobacillus plantarum TN635. Appl Biochem Biotechnol 162 (4): 1132-46.

Soria-Mercado IE, Villarreal-Gómez LJ, Guerra Rivas G, Ayala Sánchez NE. 2011. Bioactive compounds from bacteria associated to marine in algae. In: Sammour R (ed.) Biotechnology: Molecular Studies and Novel Applications for Improved Quality of Human Life, IntechOpen, UK. DOI: 10.5772/27842.

Wang L, Zhang H, Rehman M.U, Khalid Mehmood K, Jiang X, Iqbal M, Tong X, Gao X, Li J. 2018. Antibacterial activity of Lactobacillus plantarum isolated from Tibetan yaks. J Microbial Pathogenesis115: 293-298.

White TJ, Bruns T, Lee S, Taylor JW. 1990. Amplification and direct sequencing of fungal ribosomal RNA genes for phylogenetics. In PCR Protocols: A guide to Methods and Applications, Academic Press, Inc., New York. 